\title{
THE PROBLEM OF THE DIDACHE.
}

THE Didache, or Teaching of the Trvelve Apostles, has been before the world nearly thirty years. It was published in $\mathbf{I} 883$ by its discoverer Bryennius, who shewed in his learned Greek commentary that the new book had many points of contact with Christian documents already known. Further parallels were soon collected by Harnack, Rendel Harris, and other scholars. Harnack with amazing rapidity issued his great edition in $188_{4}$, and appended to it a full discussion of the origins of the Christian Ministry, basing on the new document a theory which he has since but little modified, and which in its main features has been widely accepted. A few years later Dr C. Taylor argued that the first part of the book was derived almost entirely from a Jewish manual of ethical instruction, called from its opening words the Two Ways. Criticism was then directed to the reconstruction of this Jewish manual, and to the question whether it had already been in circulation as a Christian manual before it was embodied in the Teaching of the Twelve Apostles. Moreover the whole series of quotations and references in patristic literature had to be examined afresh, to see how far they were explained by the use of the Two Ways alone, and how far they implied an acquaintance with the Teacking in its fuller form. In 1900 Joseph Schlecht published a complete text of the Latin version of which a small fragment only was already known. This version offers us the Two Ways in what appears to be very nearly its original form, but as a Christian manual bearing the title De Doctrina Apostolorwn.

The result of these and other investigations has been to shew that the Two Ways, either as a Jewish or as a Christian manual, had a considerable vogue in early times; but that the Teaching of the Truelve Apostles has left comparatively few traces of its circulation-hardly any, indeed, which are of value for determining its date. Much light has been thrown on the antecedents of the first part of the book; but the second part, which deals with Church order, 
is still an unsolved riddle. It does not seem to fit in anywhere. in either time or place. The community which it presupposes is out of relation to all our knowledge of Church history. It is as much an isolated phenomenon after all our researches as when it surprised us at its first appearance. We still ask, Where was there ever a Church which celebrated the Eucharist after the manner here enjoined? Where was there ever a Church which refused to allow Aposties more than a two days' stay?

The object of the present paper is to attack the problem afresh through an investigation of the author's indebtedness to the writings of St Paul and St Luke. Such an enquiry may seem to be foredoomed to failure : for Harnack has declared that there is no decisive instance of any acquaintance with St Paul's Epistles; and that, even if it be admitted that the author had seen them, he certainly did not regard them as in any sense authoritative : moreover quite recently the late Bishop John Wordsworth pronounced a similar judgement. Now I believe that this conclusion is one which the writer fully intended should be drawn; but I shall be disappointed if I cannot shew that he has used the writings of St Paul, St Luke, and even St John, though he has been at great pains to conceal his obligations.

We must begin with an examination of the title, and an enquiry into the author's intention in framing it. Although the book is frequently referred to as the Teaching of the Apostles, it is possible that this short title ought now to be confined to the Christian recension of the Two Ways, which is preserved to us in the Latin version. The manuscript which Bryennius discovered gives us

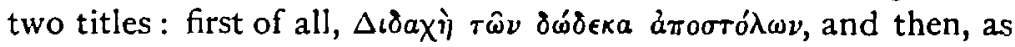

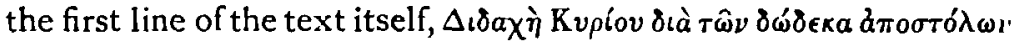

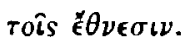

The Teaching of the Truelve Apostles may have been the brief title by which the author himself proposed that his work should be familiarly known: for it was the Apostolic tradition-the instructions delivered by the Twelve-that he claimed to record. But the ultimate sanction of the tradition is expressed in the fuller title which is an integral part of the book itself: The Teaching of the Lord through the Twelve Apostles to the Gentiles.

The substance of this longer title is undoubtedly drawn from Matt. xxviii ig f, the commission to 'the eleven disciples': 


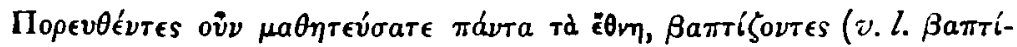

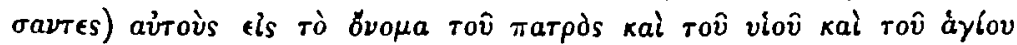

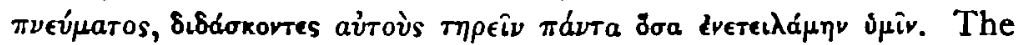
same passage is referred to after the conclusion of the moral precepts which constitute the first part of the Teaching (namely the Two Ways), when the writer in speaking of Baptism says:

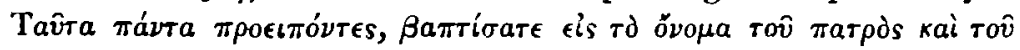

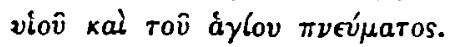

It is plain that the writer professes to record what the Apostles

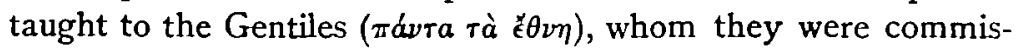
sioned to instruct and baptize. The 'eleven disciples' who are the repository of the Lord's teaching for the instruction of the Gentiles, become, by the addition of St Matthias, the Twelve Apostles; and thus we have the full explanation of the title, The Teaching of the Lord through the Twelve Apostles to the Gentiles.

How then does the writer proceed in order to produce a book which shall correspond to this title? He starts off with the words 'There are two ways', and he embodies apparently the whole of a pre-existing manual of moral instruction. It is quite possible that it lay before him in its Christian form, already entitled The Teaching of the Apostles: indeed, this title may have given him the cue for his own more elaborate work. After copying a few sentences he introduces a considerable interpolation (i $3 b$-ii I), which is largely taken from the Sermon on the Mount. He does not, however, quote our Lord's words exactly; for it is not his purpose to give us the Sayings of the Lord, but rather $\mathrm{His}$ precepts as conveyed through His Apostles: so he purposely blends the language of the First and Third Gospels, and further shews his independence by such a modification as 'Fast for them that persecute you'. We note at once this characteristic of his method : we shall have opportunities of observing it further as we proceed.

Having thus, with the welcome aid of the Two Ways, constructed a representation of the teaching given by the Twelve Apostles to the Gentiles as preliminary to Baptism, he enters upon a task demanding more originality: namely the presentation of their teaching as to the method of Baptism, the celebration of the Eucharist, and other points of Church order. It is of the first importance that we should bear in mind that what he sets 
himself to record is the teaching given by the Apostles to the Church of their day. It is not as his own book, but as theirs, that he puts out this manual of Church discipline. He has no care, as other authors had, to invent a plausible situation to explain how this teaching was formulated or came to his knowledge : he prefers to remain in the background, and allow the Teacking to win its way to acceptance on its merits. . The book no doubt is coloured by the circumstances of his own time and place; and yet so little coloured that no one has ever been able to give convincing proof either of its locality or of its date. In attempting to interpret it we must constantly remember that two elements are everywhere present: the writer's desire to say nothing that might not be supposed to have been said by the Apostles, and his desire to issue instructions which should have some bearing on the Church life of his day. It is just because he has combined these elements so skilfully, that we cannot either date or locate him.

Our author's obligations to the Two Ways end with the warning: 'See that none make thee err from this way of teaching ; otherwise he instructeth thee apart from God.' The Latin version contains a few more clauses after this :-

' Haec in consulendo si cottidie feceris, prope eris vivo deo : quod si non feceris, longe eris a veritate. haec omnia tibi in animo pone, et non decip(i)eris de spe tua; sed per haec sancta certamina pervenies ad coronam; per dominum Iesum Christum regnantem et dominantem cum deo patre et spiritu sancto in saecula saeculorum. Amen.'

Our author has nothing of this. Indeed, he has quite another message : for, in contrast to the requirement that all the precepts must be observed, he introduces the principle of a higher and a lower standard of Christian living. Two passages of St Matthew's Gospel are ringing in his ears: 'Ye shall be perfect, as your heavenly Father is perfect ' ( $\mathrm{v} 48$ ), and 'If thou wilt be perfect, go, sell that thou hast, and give to the poor' $\left(x_{1 \times} 21\right)$. On the first he has already played in his interpolation from the Sermon on the Mount: "Turn to him also the other cheek, and thou shalt be perfect'; and both are in his mind in the words which follow here :-

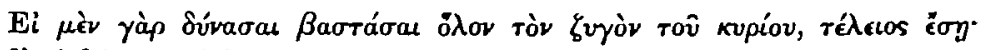

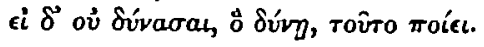




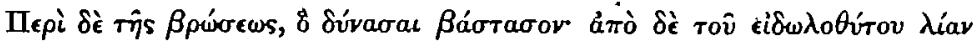

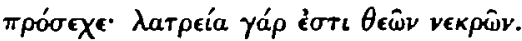

These words form the transition from the first to the second part of the Teaching, and they deserve to be studied with care. We must begin by asking ourselves, What Apostolic sanction could the writer have found for this doctrine of a higher and a lower observance, and for the precept 'Do what thou canst'? We naturally think first of the Conference at Jerusalem, which refused to lay on the Gentiles a yoke that even Jews found too heavy to bear, but yet insisted that they must by all means abstain from meats offered to idols. Here we discover much of

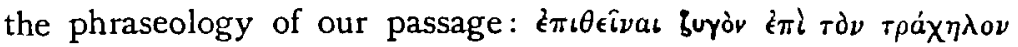

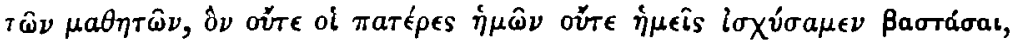

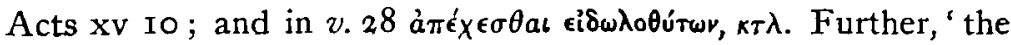
yoke of the Lord' recalls 'My yoke '(Matt. xi 29). ${ }^{\text {' }}$

But although the passage in the Acts is indubitably in the writer's mind, it does not really sanction two possible courses, a higher and a lower, but rather makes a distinction between Jewish and Gentile converts in regard to ritual requirements. Such a sanction is, however, found in St Paul's advice concerning Virgins in I Cor. vii $25-40$, where we have a series of examples in which the Apostle offers two permissible courses, of which one in his judgement is the better and more consonant with Christian

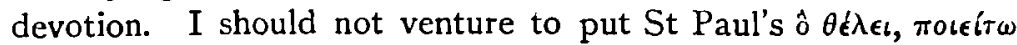

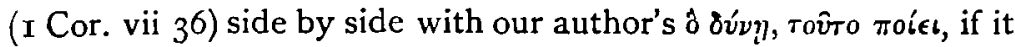
were not that there is strong reason for believing that considerable use has been made in the Teaching of this part of the Corinthian Epistle. ${ }^{2}$. The very next topic to which the Apostle turns is the question of idol-meats, and there is a curious coincidence, if it be

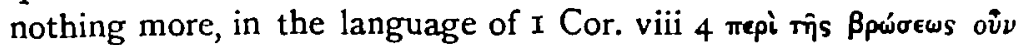

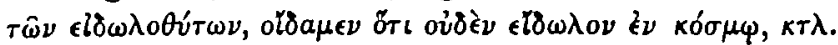

But indeed I think we shall have to admit that there is more than coincidence, or at any rate that there are at this point more coincidences than one. Let us observe how the Apostle divides

1 The worship of 'dead gods' is a phrase possibly suggested by the reference to 'the living God' (prope eris vivo dro), if we may suppose that the Latin version as quoted above continues to represent the original which was before our author.

2 St Paul's argument is based on the transitoriness of the present world : rapáyet

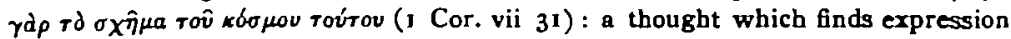

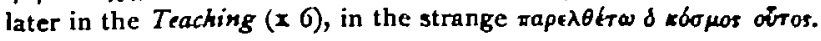


this part of his Epistle into sections introduced by the formula 'Now concerning . . .'

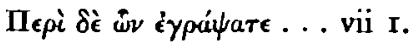

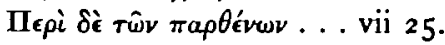

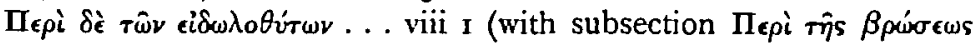
oủv. ... viii 4).

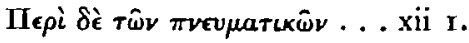

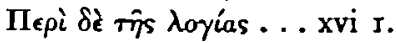

ПIєрi $\delta \grave{e}$ 'A

It is certainly curious that, as soon as our author has done with his document, the Two Ways, and begins to write with a free hand, he adopts a similar method:-

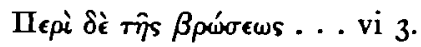

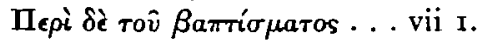

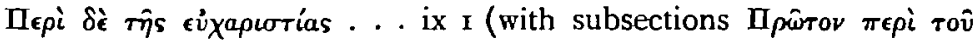

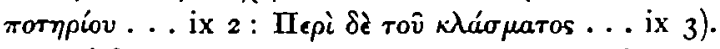

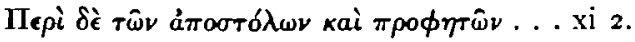

The observation of this parallel in structure may incline us to give more weight than we otherwise should to the parallels in language which we have already noted, and to those which will presently come before us.

Our author now proceeds to treat the subject of Baptism. We have already observed that the earlier portion of the book is regarded as the instruction which the Apostles gave to the Gentiles before baptizing them, and that the formula is that which is given in Matt. xxviii 19. We have only to add that, in view of later correspondences, there is reason to think that the ' living water' ( $\forall \delta \omega \rho \zeta \omega \nu)$, which is ordered to be used if possible, is a phrase which has been borrowed from St John.

The mention of the pre-baptismal fast leads our author on to speak of fasting more generally. $\mathrm{He}$ is now back again at the Sermon on the Mount; and the injunction, 'Let not your fasts be with the hypocrites; for they fast on the second day of the week and on the fifth; but do ye fast the fourth day and the preparation', shews how he can seize upon the sacred words and yet depart entirely from their spirit in the new application which he is concerned to make of them.

'Fasts' and 'hypocrites' suggest the next topic: 'Neither pray 
as do the hypocrites; but as the Lord hath commanded in His Gospel, so pray ye: Our Father ...' 'The Gospel' is mentioned again in xi $3, \mathbf{x v} 3,4$. The Twelve Apostles can assume that the Gospel in a written form is already in the hands of their converts. It is probable that the writer supposed that St Matthew's Gospel was in circulation in the lifetime of the Twelve Apostles; for it is to that Gospel that he is plainly referring. But it is certain that he himself was acquainted also with the Gospels of St Luke and St John. He will not even give the Lord's Prayer without

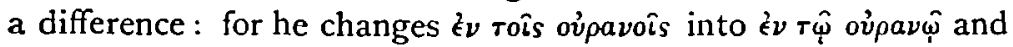

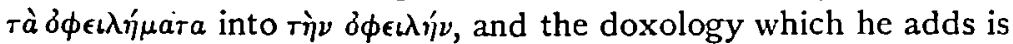

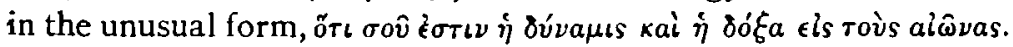
He does not add ' $A \mu \eta \dot{ } v$, a word which he reserves for the Eucharist. It is of course possible that his variations represent a liturgical tradition, for which he thus claims Apostolic sanction.

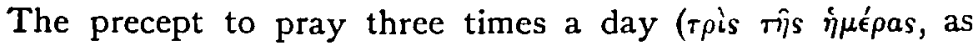
in Dan. vi II) would find sufficient Apostolic authority in the Acts : at the third hour, when the Apostles are assembled, presumably for prayer, the Holy Spirit descends at Pentecost (ii 15 ); at the sixth hour Peter prays at Joppa (x 16); at the ninth Peter and John go up to the temple (iii 1 ), and the Gentile Cornelius prays at Caesarea ( $\times 3$ ).

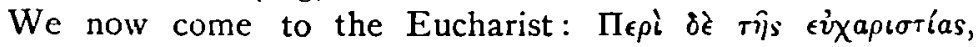

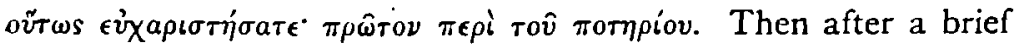

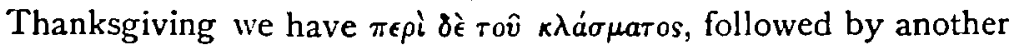
brief Thanksgiving. Here two points surprise us : first, the Cup is placed before the Bread; secondly, the word $\kappa \lambda a ́ \sigma \mu a$ in such a connexion is exceedingly odd. The first point is illustrated by I Cor. $x$ 16, I7 :-

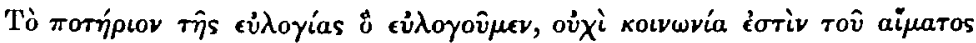

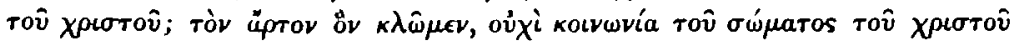

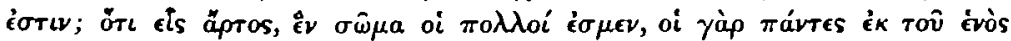

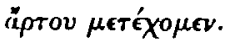

The only other parallel for this order in early Christian literature is Lk. Xxii I4 $\mathrm{f}$. We have seen enough of our author to be ready to believe that this is a piece of literary perversity on his part, and does not represent the practice of any Christian community. A few lines later he recurs to the usual order when 


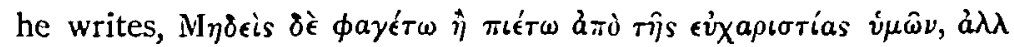
of $\beta a \pi \tau\llcorner\sigma \theta \epsilon \nu \tau \epsilon s \kappa \tau \lambda$. ; just as, indeed, St Paul himself does in xi 28

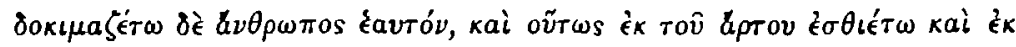

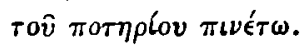

The passage in St Paul has provided our author with something more than this derangement of the usual order. It is possible that it has suggested to him the blessing of the Cup and of the Bread separately, each with a special Thanksgiving. And it is very probable that his picturesque illustration of the grains of corn scattered on the mountains and brought together into one loaf is a fancy elaborated to match St Paul's illustration of the unity of those who partake of the portions of the one loaf. We shall return to our author's illustration presently and examine its phraseology.

Meantime we must consider $\kappa \lambda \dot{\alpha} \sigma \mu a$. To such a use of the word as we have here there is no parallel, says Harnack, to be found in the literature of the first two centuries. Again our author is perverse: if he does not use otvos but $\pi$ orípเov, according to custom, he will not use ă $\rho$ ros but invents a new technical term $\times \lambda \dot{\sigma} \sigma \mu a$. What has suggested it to him? The

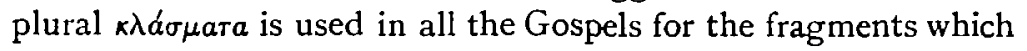
remain over when the multitude has been fed. St John who regards the incident as a symbol of the Eucharist uses $\kappa \lambda \dot{a} \sigma \mu a r a$

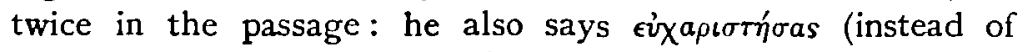

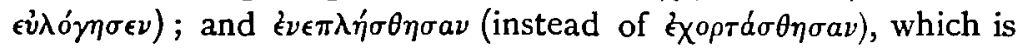

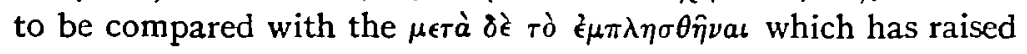
much discussion in the Teaching (iv I). That this is the source of $\kappa \lambda \dot{\alpha} \sigma \mu a$ we shall probably be prepared to admit, when we have examined the language of the Prayer which follows the second of the Thanksgivings. Let us first set the two Thanksgivings side by side :-

For the Cup.

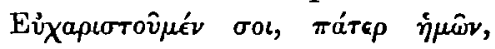

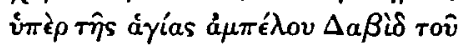
Tauó́s oov,

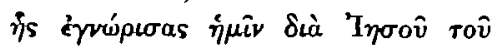

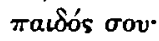

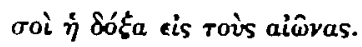

\section{For the Broken Bread.}

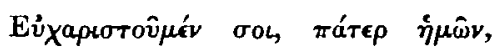

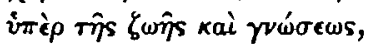

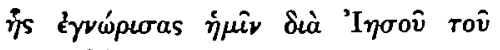

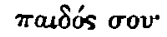

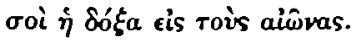

It has been held that the Eucharistic formulae of the Teaching 
were probably borrowed from some current liturgical use and were not the free composition of our author. This view has been based on the unmistakeable signs of Johannine vocabulary which they present, and the supposed absence of any traces of St John's Gospel in the rest of the book. It has further been held that the phraseology is to be accounted for not by direct use of the Fourth Gospel, but by the prevalence of such phraseology in the district in which both these formulae and the Johannine writings came into existence. But I think we shall find that the Gospel of St John has been directly used here and elsewhere in the book, and that these Thanksgivings are quite characteristic of our author.

We note first that $\pi a ́ t \epsilon \rho j \mu \hat{\omega} \nu$ comes from the Lord's Prayer, which has already been given in full. Next we observe the use of mais as a title of our Lord. This is not what we should expect in a Johannine miliez. But our author is familiar with the Acts, and with the Apostolic prayer of Acts iv 24-30: and there (though probably nowhere else in all literature) we find the same

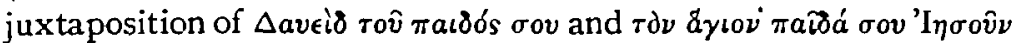

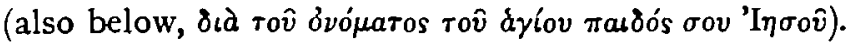

We proceed to examine the Prayer which immediately follows the Thanksgiving for the $\kappa \lambda \dot{\alpha} \sigma \mu a:-$

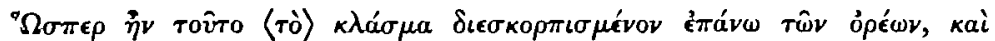

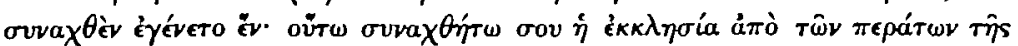

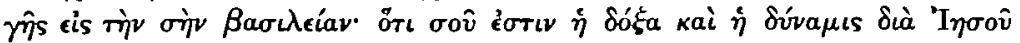

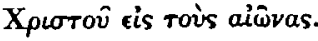

This Prayer is a literary tour de force. We have seen that St Paul, in the passage quoted above, after speaking of the blessing of the Cup and the breaking of the Bread, added words which concern the Bread alone; and we have suggested that our author's metaphor is a perverse imitation, almost a parody, of St Paul's metaphor of the unity of the loaf. We have traced the

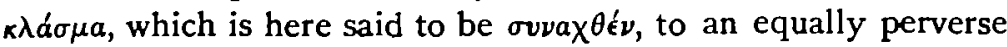

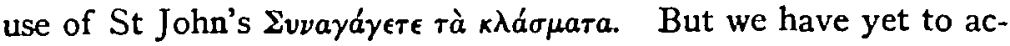
count for the awkward participle $\delta เ \epsilon \sigma \kappa o \rho \pi \iota \sigma \mu \mu^{\prime} \nu 0 \nu$, which apparently means to say that the $\kappa \lambda \dot{a} \sigma \mu a$ is composed of grains of wheat which once were widely scattered and then were brought together into

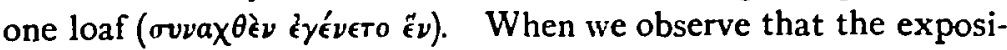


tion of the metaphor is the gathering together of the Church from all parts of the world, we cannot mistake the reference to St John's interpretation of the prophecy of Caiaphas (xi $\left.5^{2}\right)$ : I lva $_{\text {xai }} \tau \dot{a}$

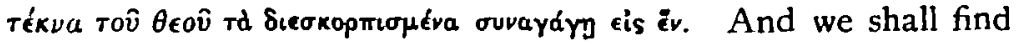
further reason later for thinking that the high priest's prophecy had taken hold of our author's imagination.

We have now to consider the closing group of Thanksgivings and Prayers, ordered to be said $\mu \epsilon \tau \grave{a} \tau \dot{\partial} \dot{\epsilon} \mu \pi \lambda \eta \sigma \theta \hat{\eta} \nu a$. It is really fruitless to enquire whether the writer had in view the combination of the Eucharist with a meal or not : such a situation would be offered to him by I Cor. xi. But the word $\epsilon^{\mu} \mu \pi \lambda \eta \sigma \theta \hat{\eta} v a l$ cannot be pressed to indicate this, now that we have traced it back together with $\kappa \lambda \delta \sigma \mu a$ to St John's narrative of the Feeding of the Multitude.

First, then, we have two Thanksgivings:-

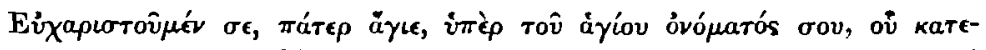

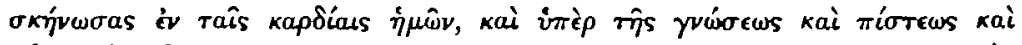

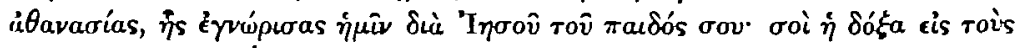
aî̄vas.

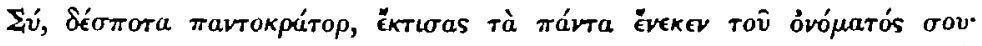

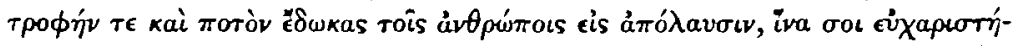

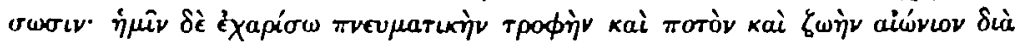

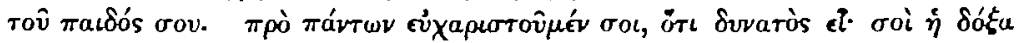
eis toùs aî̄vas.

We observe that the writer is systematic in the use of his doxologies: the short form (beginning with $\sigma 06$ ) he uses four times in Thanksgivings; the longer form (beginning with ôt $\sigma o \hat{v} \varepsilon \sigma \tau \iota \nu)$ is used at the close of the two Prayers, as he has already used it with the Lord's Prayer.

Next we note echoes of St John: comp. xvii II mátep äı,

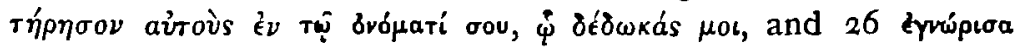

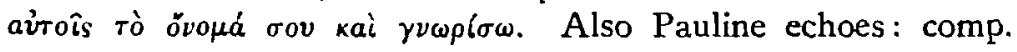

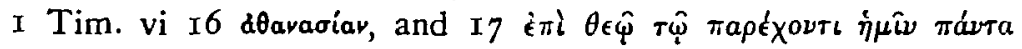

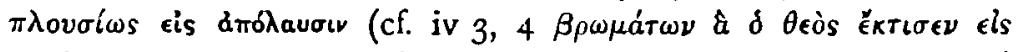

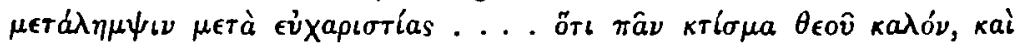

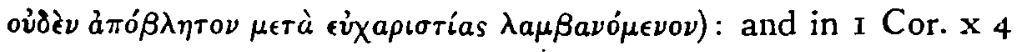

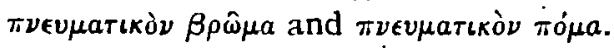

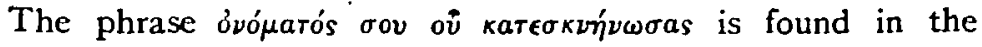
LXX of Neh. i 9, Jer. vii 12 ; and suvaròs Ei, Kúple, is in Ps. 


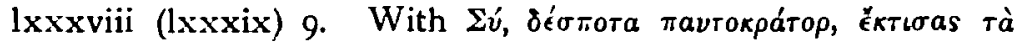
iávra we may compare the Apostolic prayer from which our

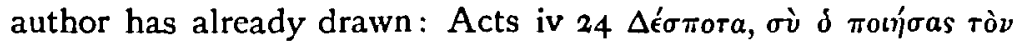
oùpavóv, $\kappa \tau \lambda$.

After these two Thanksgivings comes the following Prayer:-

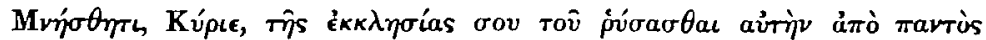

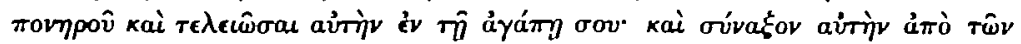

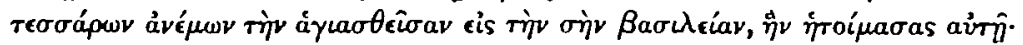

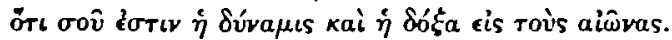

With this we may compare Matt. vi I3, xxiv 3 I, $\mathrm{xxv} 34$, and

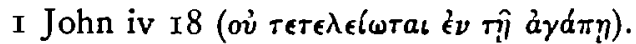

Last of all, we have a remarkable group of ejaculations :-

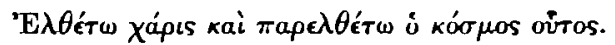

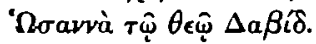

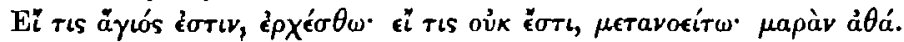

'A $\mu$ '́n.

The first of these ejaculations may remind us of I Cor. vii $3^{I}$

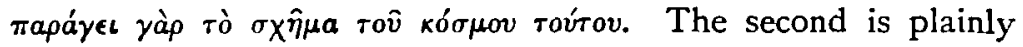
from Matt. xxi 9, I5; but with a modification, after our author's manner, probably based on Matt. xxii 45 'If David therefore calleth him Lord, how is he his son?'

With the third we must compare, for structure as well as

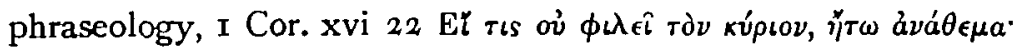

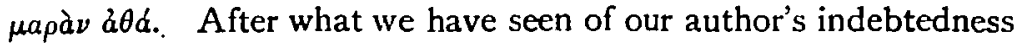
to I Corinthians we can have no doubt that this verse is in his mind at this point.

Lastly, the 'A $\mu$ in with which he closes his Eucharistic formulae, and which he has carefully refrained from using up to this point, doubtless comes from I Cor. xiv I6 'E

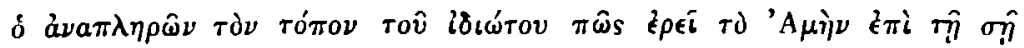
Exxaptoriq; This passage also gives us the clue to the brief sentence with which he ends his directions as to the Eucharistone of the most unexpected sentences in the whole of the book:

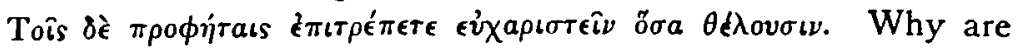
the Prophets suddenly introduced here, when no mention of them has been made hitherto? And what warrant is there anywhere for the celebration of the Eucharist by a Prophet? If eix $\alpha \rho \iota \sigma \tau i a$ in 
this passage of St Paul be taken in the later technical sense of the Eucharist, and if by 'blessing in the spirit' St Paul is supposed to mean the blessing of the elements by a Prophet, we have at once the required Apostolic sanction not only of the celebration of the Eucharist by Prophets, but also of a certain freedom in their performance of the rite.

When we have travelled thus far, and have recognized how intimately acquainted the writer of the Teaching was with the First Epistle to the Corinthians, how he has imitated its subdivisions, borrowed its words and phrases, and modified its thoughts to suit his own purposes, we are inclined to ask whether certain other notable features of his book, besides the celebration of the Eucharist by the Prophets, may not be derived from the same source. For example, the fact has been much insisted on that he addresses his injunctions to the community and not to any officers of the community, even when he prescribes rules for Baptism and the Eucharist. The Tzoo Ways is addressed to a

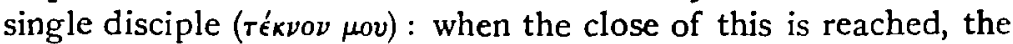
singular number is kept for a couple of sentences; but then we

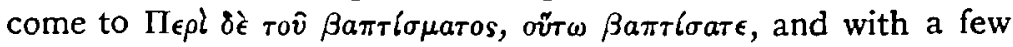
exceptions the plural is henceforth employed. It is quite likely that this mode of giving injunctions even as to ecclesiastical ceremonies in the form of an address to the whole community is simply taken over from St Paul, and is therefore to be regarded as a trick of the writer and no proof at all that he recognized any 'sovereignty of the community' in such matters.

I am tempted to go a step further and enter on more controversial ground. The Apostles, Prophets, and Teachers, of whom so much has been written since the book was discovered, have appeared to me increasingly unreal the longer I have contemplated them and the more I have tried to find any true parallel to them in any part of the Church. The Apostles are particularly shadowy personages, and the little that is said of them is simply grotesque. Here is the whole of it:-

'Now concerning the apostles and prophets, according to the command of the Gospel, so do ye. And let every apostle coming to you be received as the Lord. But he shall not remain save one day, and if there be necessity a second also; but if he remain three, he is a false prophet. And when he goeth forth let the apostle take nothing, save 
only bread till he find lodging ; but if he ask for money, he is a false prophet.'

Who are these extraordinary beings, bearing an honoured name, of whom nothing but a most depreciatory warning is uttered? Hilgenfeld was driven to think they were Montanist apostles: 'Harnack,' he says, ' regards them as itinerating evangelists, but he cannot shew that such evangelists were called apostles by Catholic writers.' I confess that I think it more probable that they are a free creation of the writer, who had in his mind St Paul's words in I Cor. xii 28 'God hath set in the church first apostles, secondly prophets, thirdly teachers'. How was his picture of the Church to which the Twelve Apostles addressed their injunctions to be duly drawn, if he left out Apostles and proceeded at once to Prophets, of whom doubtless he knew something, though but little to their advantage? $\mathrm{He}$ knew, as we know, that in the New Testament other Apostles are mentioned besides the Tivelve; not only true Apostles, but also 'false apostles, deceitful workers, transforming themselves into apostles of Christ' (2 Cor. xi 13 ). He may possibly have known of travelling evangelists, passing to mission-fields, and may have thought the term 'apostle' applicable to them : but if so, his experience of their kind was not fortunate, for he thought it quite likely that they might only prove to be another form of false prophet. At any rate, St Paul had given to Apostles, Prophets, and Teachers the first places in the Church: therefore something must be said about Apostles.

The Prophet was more of a reality. $\mathrm{He}$ is somewhat in awe of him, and is afraid to judge of his utterances. St Paul, indeed,

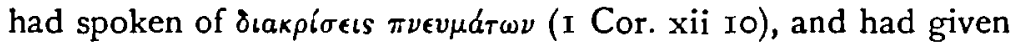

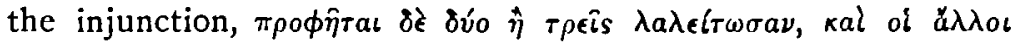

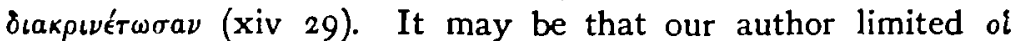
$a \lambda \lambda a c$ to the other Prophets; at any rate he forbids the community

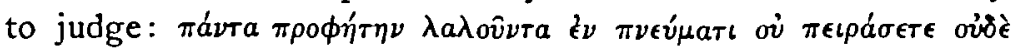
siaxpıveite-for this, he adds from Matt. xii $3 \mathrm{I}$, is the unforgiveable sin. Some of them acted in a way that ordinary men would not be justified in imitating : yet perchance they were but following the precedent of some of the Old Testament prophets, whose strange actions were meant for a sign : their judgement was with God. His only resource against the numerous class of deceivers 
is to enjoin that they be well tested before they are accepted as true prophets, and to lay down the simple rule that greediness is the sure sign of the false prophet.

From St Paul he had gathered, as we have seen, that Prophets might 'bless in the spirit' at the Eucharist, and therefore could not be limited to prescribed formulae. This is a sufficiently surprising statement, but now follows something more startling still : 'they are your high priests.' This is not said in reference to the Eucharist, though he twice speaks of that as a sacrifice, borrowing the word from Malachi. It is said in reference to the reception of firstfruits. He is making provision for a Prophet who desires to settle in a community. To him the Lord's words will apply, 'he is worthy of his meat.' 'Every firstfruit therefore of the produce of wine-press and threshing-floor, thou shalt

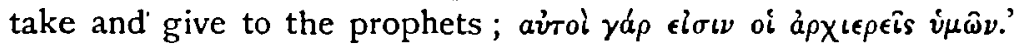
In further enumerating kinds of firstfruits he twice uses the expression 'give according to the commandment'. No such commandment can be deduced from our Lord's words in St Matthew's Gospel: where then has he found his sanction for transferring the Jewish system of firstfruits to provide for the sustenance of Christian Prophets? If we turn again to the First Epistle to the Corinthians, we find what we want in a command of the Lord which was certain to attract his attention (ix I3) :-

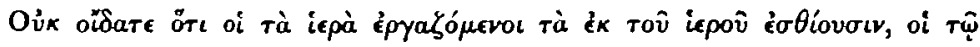

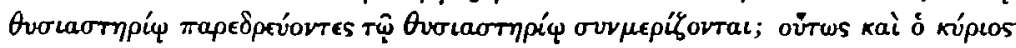

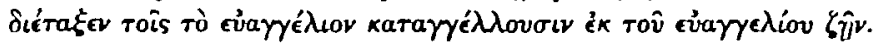

The Lord had said that they who preach the Gospel should live of the Gospel, and St Paul had given as the reason for this that the priests in the temple were accustomed to live of the altar. This is enough for our author, who transfers a list of firstfruits from the Book of Numbers, where they are ordered to be given to the priests, and thus makes an abundant provision for the Prophets, 'for they are your high priests'. We have thus accounted for the provision, but not altogether for the desig-

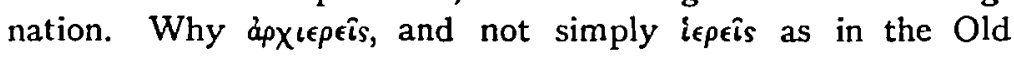
Testament passage from which he has drawn? We have already seen how he has borrowed a striking phrase from the interpreta- 
tion given by St John to the words of Caiaphas (xi $5 \mathrm{I} f$ qva . . .

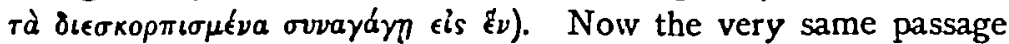
declares that the high priest, in virtue of his office, spoke as a

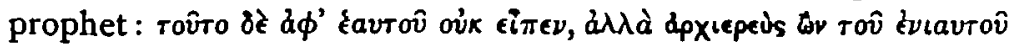
ékelyov expophrevoev. If their high priests were prophets, the Prophets 'are your high priests'.

The Teacher is added to the Prophet in a rather perfunctory

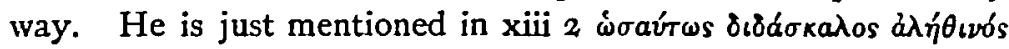

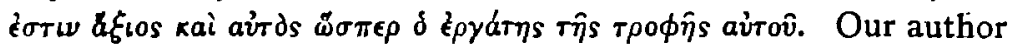
knows that Teachers come next to Prophets in St Paul's list, and he links them with Prophets in xv I, 2. But he has nothing to tell us about them as a separate class.

But if Apostles, Prophets, and Teachers are the prominent personages of the Church, whether as occasional visitors or as making a prolonged stay, what of the ordinary government of a Christian community? Had the Twelve Apostles left no directions about that? When he has done with the Prophets, and has given some rules as to the Sunday Eucharist and its preliminaries of confession and reconciliation, he proceeds to speak of those who would ordinarily be responsible for worship and discipline: 'Appoint therefore for yourselves bishops and deacons, worthy of the Lord, men who are gentle and without covetousness and true and proved : for they also minister to you the ministry of the prophets and teachers. Therefore despise them not, for they are your honoured ones together with the prophets and teachers.' $\mathrm{He}$ had Apostolic warrant for Bishops and Deacons in Phil. i I and in the Pastoral Epistles. From the latter source he draws his epithets, though somewhat

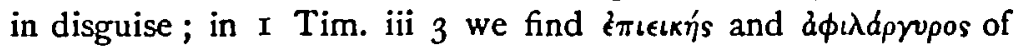

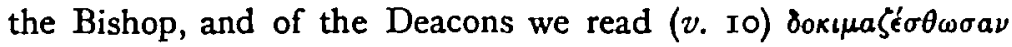
$\pi \rho \hat{\omega}$ Tov. But what chiefly interests us is the ground which he

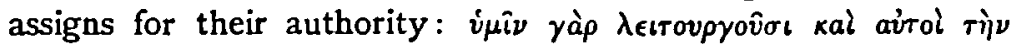

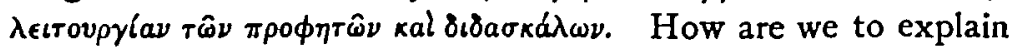

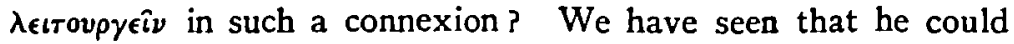
find but little to say about Teachers, and that he merely linked them on to the Prophets. Now apart from I Cor. xii 28 there is only one passage which brings Prophets and Teachers immediately together: for in Eph. iv I I Evangelists and Pastors come in between. This passage is Acts xiii 1,2 'There were at VOL. XIII. 
Antioch, in the church there, prophets and teachers . . . and as they were ministering to the Lord', \&c. St Luke has derived

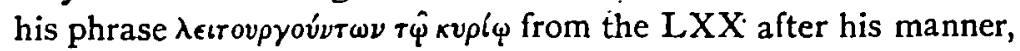
taking it over from I Sam. iii I, where the young prophet Samuel was 'ministering to the Lord' ( $\hat{\eta} \nu \lambda \epsilon \iota \tau o v \rho \gamma \hat{\omega} \nu \tau \hat{\varphi} \kappa v \rho(\varphi)$ ). It is interesting to see how far the phrase has travelled.

The writer of the Teaching had doubtless to face the fact that the functions which he ascribes to Prophets were in his own.day being performed by Bishops. But he had no Apostolic warrant for the celebration of the Eucharist by a Bishop, such as he had contrived to find in St Paul for its celebration by a Prophet. He succeeds, however, by the aid of Acts xiii 1, 2, in building a sort of bridge between Prophets and Teachers on the one side and Bishops and Deacons on the other. What was the actual constitution of the Church in which he lived, he does not enable us to determine. He may have identified Bishops and Presbyters, as he makes no mention of the latter; but such a conclusion is precarious. And as the instructions which he gives are those of the Twelve Apostles who are addressing 'the Gentiles' generally and not any particular community, we can draw no argument from his use of the plural 'bishops and deacons' to decide whether he thought of a single Church as ruled by one Bishop or by several.

If our conclusions are justly drawn, it must be recognized that the writer of the Teaching, so far at any rate as matters of Church organization are concerned, confines himself as strictly as he can to what the Twelve Apostles might reasonably be held to have enjoined, and bases his instructions on what he believes he can draw from the Apostolic writings. He disguises his borrowings indeed; but he also disguises the actual conditions of his own time. The result is that he contributes almost nothing, except doubtful exegesis, to advance our knowledge of the early Christian ministry.

This enquiry is far from being exhaustive. I have pointed to a method of composition which the writer of the Teaching has certainly employed. That method can be traced farther than I have traced it here : for I have not attempted to cover the whole ground, and indeed have not touched upon the apocalyptic section with which the book closes. My purpose has been to 
indicate an element which has been strangely overlooked in the criticism of this much quoted manual. I wish to provoke discussion.

If what $I$ have said be in the main accepted, certain prominent features of the book will cease to be more than literary curiosities. And then we must ask what notable features remain unexplained, and incapable of explanation, on the principle of deduction from apostolic writings. The kinds of water allowable for Baptism, and the bi-weekly fast-these at once suggest themselves: and (though the writer perhaps thought he found Apostolic sanction for them) the custom of praying thrice a day and the recognition of the professional Prophet may also be regarded as positive features, characteristic of the writer's situation. On the other hand 'silences' of the Teacking will be no secure guide. We shall not be at liberty to conclude that the writer knew nothing of a liturgical consecration of the eucharistic elements as the Body and Blood of the Lord, or of carrying the Eucharist to the absent, or of the Paschal fast and the Easter festival. For he may have been quite familiar with these things, and have omitted them simply for want of what he considered a definite Apostolic sanction.

Other questions to be considered afresh will be: Why is there no reference to Christian theology or soteriology in connexion with the preparation for Baptism? Why are there no allusions to persecution by the heathen ? Why is St Paul never mentioned, though his epistles are laid under contribution? What after all was the writer's object in composing the book?

I do not propose to follow Dr. Bigg, who for quite different reasons from any which I have been suggesting placed the Teacking in the fourth century. ${ }^{1}$ I should find it rather hard to conceive that it was written after Montanism had attained any considerable vogue. For from the orthodox standpoint there is too much said about Prophets, and from the Montanist standpoint there is too little; and there is nothing at all about women. Apart from pointing this out I make no suggestion

1 It may be well to add that I had not seen Dr Bigg's little book, The Dodrine of the Twelve Apostles (London S.P.G. 1898), until after I had written the above. The popular form in which his work was published may perhaps be the reason why his trenchant criticisms have received so little attention. 
as to a date, though I am ready to believe that both Barnabas and Hermas have been used.

I ask for a reconsideration of the problem. The question is not whether this or that feature of the book is susceptible of a better explanation than I have offered, but whether the writer's method was in reality such as I have supposed. Some of the points which I have taken may be dismissed as over-subtle; but if even half of what I have put forward be admitted by serious students, the pen must be drawn through many a sentence, and indeed through whole pages, of some recent descriptions of early Church life and organization.

J. Armitage Robinson. 